\title{
Pengaruh Subtitusi Kelapa Parut (Cocos Nucifera) dalam Pembuatan Kue Sagon Kabocha (Cucurbita Maxima. L) sebagai Inovasi Kuliner Magetan
}

\author{
Maulida Ahyana Laily*, Budi Wibowotomo, Laili Hidayati \\ Universitas Negeri Malang, Jl. Semarang No. 5 Malang, Jawa Timur, Indonesia \\ *Penulis korespondensi, Surel: budi.wibowotomo.ft@um.ac.id
}

Paper received: 05-02-2021; revised: 18-02-2021; accepted: 30-02-2021

\begin{abstract}
Abstrak
Kue sagon makanan tradisional tersebar Indonesia terdiri tepung ketan putih, kelapa parut, gula, telur dipanggang, disajikan agenda besar. Inovasi subtitusi kabocha dengan kelapa parut mengetahui gizi, rasa, tekstur dan warna kue sagon. Subtitusi terdiri 3 formula yaitu kue sagon subtitusi kabocha 60 persen: kelapa parut 40 persen, kabocha 70 persen: kelapa parut 30 persen dan kabocha 80 persen : kelapa parut 20 persen. Hasil uji proksimat (protein, karbohidrat, air, lemak, abu dan serat pangan) nilai tertinggi sampel kue sagon subtitusi kabocha 60 persen: kelapa parut 40 persen protein $(14,541 \mathrm{gr} / 100 \mathrm{gr}$,$) , lemak (17,71 \mathrm{gr} / 100 \mathrm{gr})$ dan abu (5,737 gr/100 gr). Nilai bagian tertinggi uji proksimat pada sampel kue sagon subtitusi kabocha 80 persen: kelapa parut 20 persen karbohidrat (58,272 persen), air (11,5645 gr/100 gr) serat pangan (45,4635 gr / 100 gr), kandungan beta karoten tertinggi 1188,142 gr /100 gr.
\end{abstract}

Kata kunci: kue sagon kabocha; kelapa parut; inovasi kuliner

\section{Pendahuluan}

Kue sagon merupakan makanan yang tersebar di beberapa daerah Indonesia terbuat dari parutan kelapa matang, tepung ketan dan telur yang dicampur kemudian di oven (Gardjito dkk 2017). Kabocha mengandung berbagai zat gizi, terutama betakaroten (provitamin A), vitamin $\mathrm{C}$, karbohidrat, dan serat pangan. Ciri fisik labu jepang cukup menarik, warnanya kebanyakan oranye, ukurannya kecil sampai sedang dengan berat bervariasi, dan mempunyai kulit yang tidak terlalu tebal dan keras (Kusbiantoro, dkk 2005).

Kandungan karotenoid (provitamin A) yang tinggi $285.9 \mathrm{mg} / 100 \mathrm{~g}$ dibandingkan labu kuning biasa sebesar 24,62 mg/ 100g dan senyawa yang larut dalam lemak yang menghasilkan warna merah, orange dan kuning (Manasika \& Widjanarko, 2015). Salah satu kandungan yang menonjol dari kabocha adalah beta karoten atau provitamin A memiliki sifat tahan terhadap panas dan cahaya, pro vitamin A akan aktif jika terdapat bahan pangan hewani sehingga menjadi vitamin A (Adriani \& Wijatmadi, 2012) fungsi betakaroten metabolisme komponen utama berperan aktif d sel pencegahan kanker (Ross, 2000).

Sedangkan panen kabocha yang 702,33 kg dalam satu musim tanam dengan lokasi budidaya di kecamatan Plaosan Kabupaten Magetan (Ardhyani dkk, 2015). paparan teori diatas penelitian ini berjudul "Subtitusi Kelapa Parut (cocos nucifera) dengan Kabocha (cucurbita maxima.l) dalam Pembuatan Kue Sagon sebagai Inovasi Kuliner Magetan".

Inovasi kue sagon mengetahui kandungan proksimat (protein, karbohidrat, air, lemak, abu dan serat pangan) dan kandungan betakaroten , uji fisik warna dan daya patah serta uji organoleptik seperti mutu hedonik (rasa) dan sifat hedonik ( rasa, warna dan tekstur). 
Penelitian ini diharapkan dapat bermanfaat bagi penelitian, pembaca dan lembaga yang digunakan sumber data, aplikasi pengolahan atau penelitian selanjutnya.

\section{Metode}

\subsection{Bahan dan Alat}

Kabocha yang matang, diperoleh dari pasar sarangan kecamatan plaosan kabupaten magetan. Kelapa parut setengah tua, tepung ketan putih, putih telur, mentega, gula halus, soda kue dan vanili. Bahan-bahan lain untuk analisis uji proksimat dan betakaroten. Alat yang digunakan adalah oven, mixer, cetakan kue, timbangan analitik, soxhlet, ayakan tepung, baskom, kompor, serbet, sendok kue, cawan, labu kjeldahl, alat ekstraksi, ruang asam, erlenmeyer, Destilat, desikator, cawan pengabuan, tanur, pendingin balik, waring blender, filtrat, indikator $\mathrm{pH}$, filtrat, Pemanas berjaket, Bidwell-Sterling,Kondensor tipe cold finger

\subsection{Rancangan Percobaan}

Penelitian eksperimen dimaksudkan untuk melihat pengaruh substitusi antara kelapa parut dengan kabocha yang diaplikasikan. Penelitian menggunakan Rancangan Acak Lengkap (RAL) dengan satu faktor 3 level. Perlakuan dilakukan peneliti subtitusi kabocha dengan kelapa parut dicampur, kemudian dikeringkan dengan substitusi kabocha 60\%: kelapa Parut 40\%, Kabocha 70\% : Kelapa Parut 30\% dan Kabocha 80\% : kelapa Parut 20\%. Uji Analysis of Variance (ANOVA) menunjukan perbedaan signifikan dilanjutkan dengan Duncan Multiple Range Test (DMRT) digunakan menguji kimia kadar proksimat (proksimat, karbohidrat, air, lemak, abu dan serat pangan) berdasarkan Association of Official Analytical Chemists (AOAC) dan uji beta karoten metode Spektrofotometri.

\subsection{Prosedur Penelitian}

Kelapa dengan kematangan yang sedang dikupas dari mulai serabut kelapa, batok kelapa dan kulit kelapa hingga berwarna putih. Keluarkan air kelapa, potong menjadi 4 bagian lalu dicuci hingga bersih kelapa diparut dengan panjang 0,5-1 cm, disangrai hingga warna putih kekuningan dengan suhu 60 。C selama 30 menit.

Kabocha dengan berat 1- 1,5 kg dikupas lalu dibuang biji dicuci bersih Potong kabocha dengan tebal $0,5 \mathrm{~cm}$ kemudian dimasukkan ke dalam oven selama 30 menit dengan suhu $60^{\circ} \mathrm{C}$. Setelah kabocha disterilisasi giling kabocha dengan food processor hingga menjadi puree kental.

Puree kabocha dan kelapa parut dengan perbandingan 60\%: 40\% ; 70\% : $30 \%$; 80\% : $20 \%$ hingga warna homogen tiap perlakuan Lapisi loyang dengan kain bersih agar puree kabocha dan kelapa parut sangrai telah dicampur menghindari kontak langsung ke pengeringan yang menyebabkan gosong.Keringkan puree kabocha dan kelapa parut sangrai menggunakan sterilizer dengan suhu 50॰C selama 18 jam, pantau dan aduk setiap 2 jam sekali agar tidak menggumpal kabocha kelapa kering.

Sangrai tepung ketan putih dengan suhu 60 •C selama 30 menit lalu dinginkan. Kocok putih telur, gula, vanili dan mentega dikocok hingga merata, tambahkan tepung ketan dan serbuk kabocha kelapa kering aduk hingga warna menjadi homogen Cetak adonan dengan 
ketebalan 0,5 cm berbentuk lingkaran dengan diameter 1,5 cm. Panggang adonan yang telah dicetak dalam oven dengan suhu $100 \cdot \mathrm{C}$ selama 60 menit.

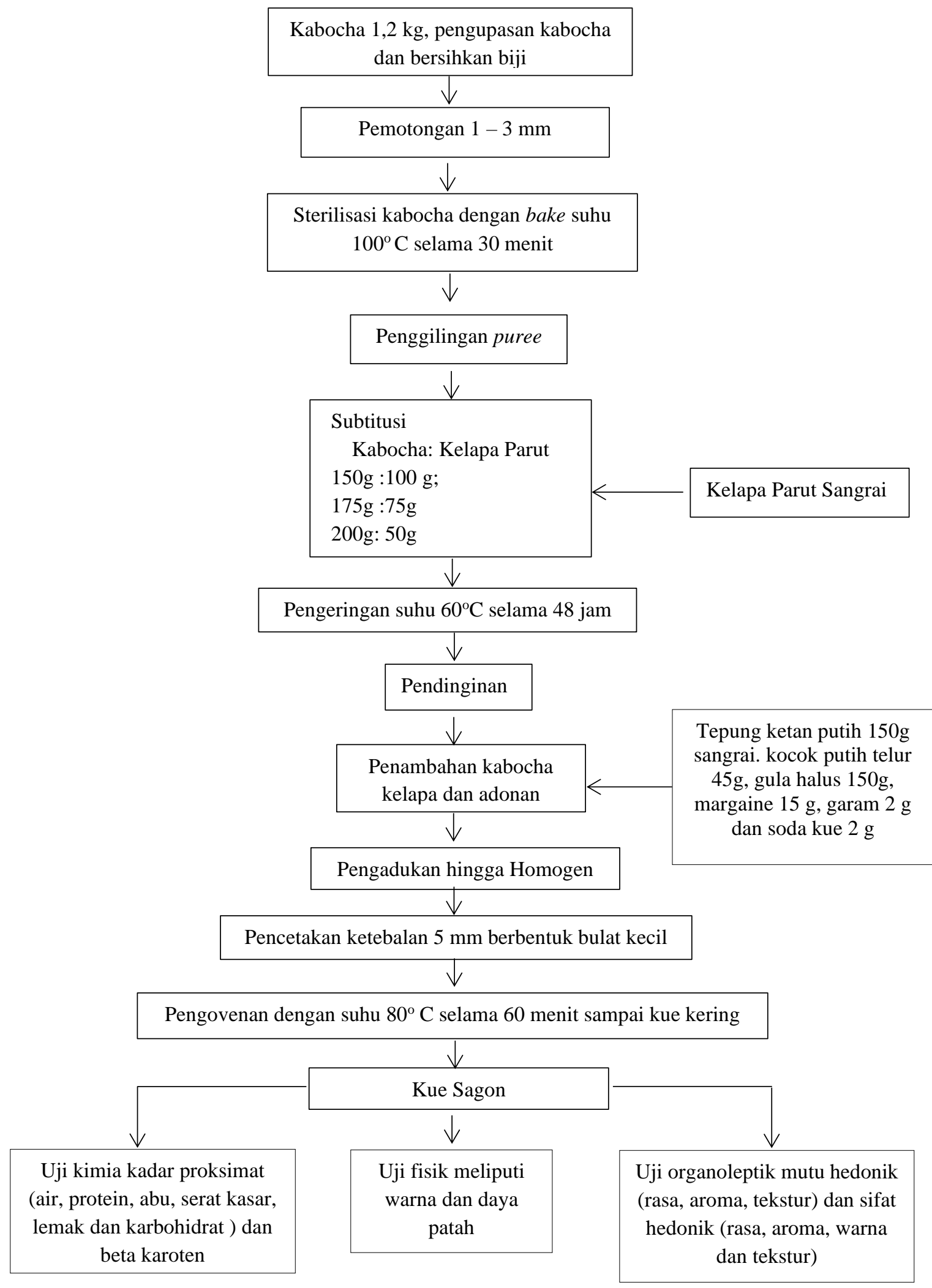

Gambar 1. Diagram modifikasi pembuatan sagon kabocha 
3. Hasil dan Pembahasan

Tabel 1. Uji Proksimat (Protein, Karbohidrat, Lemak, Air, Abu, Serat Pangan ) dan uji beta karoten

\begin{tabular}{lllllll}
\hline $\begin{array}{l}\text { Kabocha: Kelapa } \\
\text { Parut (\%) }\end{array}$ & $\begin{array}{l}\text { Kadar } \\
\text { Protein } \\
\text { (g/100g) }\end{array}$ & $\begin{array}{l}\text { Kadar } \\
\text { karbohidrat } \\
\text { (\%) }\end{array}$ & $\begin{array}{l}\text { Kadar } \\
\text { Lemak } \\
\text { (g/100g) }\end{array}$ & $\begin{array}{l}\text { Kadar } \\
\text { Air } \\
\text { (g/100g) }\end{array}$ & $\begin{array}{l}\text { Kadar } \\
\text { Abu } \\
\text { (g/100g) }\end{array}$ & $\begin{array}{l}\text { Kadar } \\
\text { Serat } \\
\text { Pangan } \\
\text { (\%) }\end{array}$ \\
\hline $\begin{array}{l}\text { Kabocha 60\%: } \\
\begin{array}{l}\text { Kelapa Parut 40\% } \\
\text { Kabocha 70\%: }\end{array}\end{array}$ & 14,541 & 52,059 & 17,71 & 9,9525 & 5,737 & 42,1705 \\
$\begin{array}{l}\text { Kelapa Parut 30\% } \\
\text { Kabocha 80\%: }\end{array}$ & 13,256 & 54,6985 & 15,873 & 10,931 & 5,237 & 43,802 \\
Kelapa Parut 20\% & 11,871 & 58,272 & 13,527 & 11,564 & 4,7255 & 45,4635 \\
\hline
\end{tabular}

\subsection{Kadar Protein}

Protein memiliki fungsi sebagai penunjang mekanis, ketegangan kulit dan tulang, proteksi imun antibodi merupakan daya tahan tubuh mengenal serta berkombinasi dengan benda asing seperti virus, bakteri dan sel berasal organisme dan membangkitkan menghantar impuls saraf dengan respon sel saraf rangsang spesifik (Rosana D, 2008). Sehingga kadar protein kue sagon nilai tertinggi subtitusi kabocha $60 \%$ : kelapa parut $40 \%$ yaitu $(14,541 \mathrm{gr} /$ 100 gr). Hasil analisis ANOVA dilanjutkan DMRT menunjukkan terdapat perbedaan signifikan kandungan protein ketiga sampel kue sagon subtitusi kabocha kelapa parut diujikan nilai $(\mathrm{p}=0$, $000<0,05$ ).

\subsection{Kadar Karbohidrat}

Karbohidrat $\left(\mathrm{CH}_{2} \mathrm{O}\right)$ bahan energi diperlukan tubuh manusia, hewan, dan tumbuhan selain lemak dan protein. Senyawa ini dalam jaringan merupakan cadangan makanan atau energi yang disimpan dalam sel. Sebagian besar karbohidrat yang ditemukan di alam terdapat sebagai polisakarida dengan berat molekul tinggi(Manruw, 2010). Kadar karbohidrat kue sagon memiliki nilai tertinggi subtitusi kabocha $80 \%$ : kelapa parut $20 \%$ yaitu $(58,272 \%)$. Hasil analisis ANOVA dilanjutkan DMRT menunjukkan terdapat perbedaan yang signifikan antara kandungan karbohidrat dari ketiga sampel subtitusi kabocha dengan kelapa parut pada kue sagon diujikan dengan nilai $(\mathrm{p}=0,001<0,05)$

\subsection{Kadar Lemak}

Lemak dalam tubuh antara lain sebagai sumber energi, bagian dari membran sel, mediator aktivitas biologis antar sel, isolator menjaga keseimbangan suhu tubuh, pelindung organ - organ tubuh serta pelarut vitamin A, D, E, dan K. Penambahan lemak makanan memberikan efek rasa lezat dan tekstur makanan menjadi lembut serta gurih. Lemak menghasilkan energi dua kali lebih banyak dibandingkan dengan protein dan karbohidrat, yaitu $9 \mathrm{Kkal} / g r a m ~ l e m a k$ yang dikonsumsi (Angelia I.0,2016). kadar lemak kue sagon memiliki nilai tertinggi subtitusi kabocha $60 \%$ : kelapa parut $40 \%$ yaitu $(17,71 \mathrm{gr} / 100 \mathrm{gr})$. Hasil analisis ANOVA dilanjutkan DMRT menunjukkan terdapat perbedaan signifikan antara kandungan lemak ketiga sampel subtitusi kabocha dengan kelapa parut kue sagon diujikan nilai ( $p=0,000$ $<0,05)$. 


\subsection{Kadar Air}

Kadar air substrat atau $\mathrm{a}_{w}$ pada bahan pangan memiliki peranan penting menghambat atau mencegah pertumbuhan mikroba. Salah satu cara untuk menghambat atau mencegah pertumbuhan mikroba dengan mengurangi kadar air melalui proses pengeringan (Rahmawati F, 2011). Kadar air kue sagon memiliki nilai tertinggi subtitusi kabocha $80 \%$ : kelapa parut $20 \%$ yaitu $(9,9525 \mathrm{gr} / 100 \mathrm{gr})$. Hasil analisis ANOVA dilanjutkan DMRT menunjukkan terdapat perbedaan signifikan antara kandungan air dari ketiga sampel kue sagon subtitusi kabocha dengan kelapa parut diujikan nilai $(\mathrm{p}=0,015<0,05)$.

\subsection{Kadar Abu}

Analisis kadar abu penting untuk bahan atau produk pangan menunjukkan kualitas seperti pada teh, tepung, atau gelatin. Perlakuan awal untuk menentukan jenis mineral bahan atau produk pangan dan parameter penting nilai gizi pangan. Analisis pangan yang penting tidak hanya kuantitas tetapi juga abu larut dan tidak larut air, alkalinitas abu larut dan yang tidak larut asam (Estiasih, 2012). Kadar abu kue sagon memiliki nilai substitusi kabocha $80 \%$ : kelapa parut $20 \%$ yaitu $(0,0060313) \mathrm{N} / \mathrm{cm}^{2}$. Hasil analisis ANOVA dilanjutkan DMRT menunjukkan terdapat perbedaan yang signifikan antara kandungan abu dari ketiga sampel kue sagon subtitusi kabocha dengan kelapa parut diujikan nilai $(p=0,000<0,05)$

\subsection{Kadar Serat Pangan}

Serat pangan adalah komponen bahan makanan nabati yang penting yang tahan terhadap proses hidrolisis oleh enzim-enzim pada sistem pencernaan manusia, Komponen yang terbanyak dari serat makanan ditemukan dinding sel tanaman senyawa structural seperti selulosa, hemiselulosa, pectin dan lignin, istilah serat makanan (dietary fiber) harus dibedakan dengan istilah serat kasar (crude fiber) yang biasa digunakan dalam analisa proksimat bahan pangan (Tekpan, 2006). Kadar serat pangan memiliki nilai pada subtitusi kabocha $80 \%$ : kelapa parut 20\% yaitu 45,4635\%. Hasil analisis ANOVA dilanjutkan DMRT menunjukkan terdapat perbedaan yang signifikan antara kandungan serat pangan dari ketiga sampel kue sagon subtitusi kabocha dengan kelapa parut kue sagon diujikan dengan nilai $(\mathrm{p}=0,001<0,05)$.

\subsection{Kadar Betakaroten}

Tabel 2. Kadar Betakaroten

\begin{tabular}{ll}
\hline Kabocha: Kelapa Parut (\%) & Kadar Betakaroten (g/100g) \\
\hline Kabocha 60\%: Kelapa Parut 40\% & 898,113 \\
Kabocha 70\%: Kelapa Parut 30\% & 1073,589 \\
Kabocha 80\%: Kelapa Parut 20\% & 1188,142 \\
\hline
\end{tabular}

Menurut Russel dalam (Srihartati, 2015:7) $\beta$-karoten adalah pigmen utama membentuk warna merah, orange, kuning dan hijau pada buah dan sayur. Karoten mempunyai sifat fungsional sebagai antioksidan yang melindungi sel dan jaringan dari kerusakan akibat adanya radikal bebas dalam tubuh. $\beta$-karoten juga berhubungan peningkatan fungsi sistem kekebalan tubuh, melindungi kerusakan akibat paparan sinar matahari dan menghambat pertumbuhan kanker. kadar betakaroten kue sagon 1188,142 gr/100 gr terdapat pada kue sagon subtitusi kabocha 80\%: kelapa parut 20\%. Hasil analisis ANOVA dilanjutkan DMRT menunjukkan 
terdapat perbedaan yang signifikan antara kandungan betakaroten dari ketiga sampel kue sagon subtitusi kabocha dengan kelapa parut pada kue sagon diujikan dengan nilai ( $p=0,000$ $<0,05)$.

\section{Simpulan}

Subtitusi kue sagon dengan kabocha memiliki kekurangan, kelebihan dan persamaan sampel subtitusi namun ada formula terbaik seperti kue sagon subtitusi kabocha 60\%: kelapa parut $40 \%$ memiliki nilai tertinggi beberapa bagian analisis proksimat (protein 14,541 gr/100 gr, lemak 17,71 gr/100 gr, abu 5,737g /100g). Kue sagon subtitusi kabocha $80 \%$ : kelapa parut $20 \%$ Bagian analisis proksimat (karbohidrat 58,272 \%, air 11,564 gr/100 gr, serat pangan $45,4635 \%)$.

\section{Daftar Rujukan}

Angelia, I. O. (2016). Analisis Kadar Lemak pada Tepung Ampas Kelapa. Jurnal Technopreneur, 4(1), 19-23.

Ardhyani, R. Rahayu, R \& Sundari, M. T. (2015). Analisis pemasaran labu kuning (Cucurbita Maxima. L) Kecamatan Plaosan Kabupaten Magetan Jawa Timur. Agrista. 1(2), 57-67.

Estiasih, T. (2012). Kadar abu Mineral. 1- 4. Universitas Brawijaya Fakultas Teknologi Pertanian.

Gharjito. M. (2017). Kuliner Yogjakarta Pantas Dikenang Sepanjang Masa. (Hardiman.I). Jakarta: Gramedia Pustaka Utama.

Kusbiantoro, B., Herawati, H., \& Ahza, A. B. (2005). Pengaruh jenis dan konsentrasi bahan penstabil terhadap mutu produk velva labu jepang.

Manasika, A., \& Widjanarko, S. B. (2015). Ekstraksi Pigmen Karotenoid Labu Kabocha Menggunakan Metode Ultrasonik (Kajian Rasio Bahan: Pelarut Dan Lama Ekstraksi). Jurnal Pangan dan Agroindustri, 3(3).

Murdianto. W, Syahrumsyah H. \& Yanti. S, (2014). Formulasi labu kuning (CucurbitaMoschata) dan kelapaparut terhadap kararkteristik kimia sensoris pada formulasi pembuatan cookies. Jurnal Prosiding Seminar Nasional Kimia 2014.6 (3), 1-3.

Manruw S. (2010). Pengantar Biokimia. Universitas Indonesia Press. Jakarta

Rahmawati, F. (2011). Pengawetan Makanan. Yogjakarta: Universitas Negeri.Yogjakarta

Ross, S. A., McCaffery, P. J., Drager, U. C., \& De Luca, L. M. (2000). Retinoids in embryonal development. Physiological reviews, 80(3), 1021-1054.

Sarifudin, A., \& Ekafitri, R. (2015). Karakteristik Sifat Fisiko-kimia dan Thermal Serta Penerima Organoleptik Kue Sagon Berbasis Tepung Pisang.

Srihartati. (2015). Formulasi Tepung Terigu Dan Labu Kuning (Cucurbita Moschata Durch) Terhadap Sifat Fisik, Kimia dan Organoleptik Kue Bakpao.

Winarno, F. G. (2004). Kimia Pangan dan gizi. Jakarta: Gramedia Pustaka Utama 